pressure were provided. The heating by air circulation kept the temperature uniform through out the building. A design of the cages used is supplied. The findings and data, especially the mortality rate from day $\mathbf{I}$ to day ro of rearing, are indicated.

The results are not obtained from specific environmental trials where control conditions could be tested, but are based on attempts made to determine the best environmental conditions and the lowest mortality. With regard to this fact, the data indicated must not be considered as standard values.

\title{
FeEdNG Behaviour of Domestic CHICKS DURING THREE WEEKS AFTER HATCHING
}

\author{
J. GOUSSOPOULOS, Y. CARLES et M. PRUD'HON \\ Station de Physiologie animale, I. N.R. A., \\ E. N. S. A., Place Viala, \\ 34060 Montpellier Cedex
}

A device for automatic graph recording of the liquid and solic food intake in ad libitum ted domestic chicks is described. This apparatus was used to measure the food intake of four chicks during 2 I days after hatching. The chicks were reared in individual cages under two light regimes: continuous light (LI.) and 14 hours light, ro hours dark (LD). There was a significant difference in body weight at the end of the control period, LL chicks being heavier than LD. The subjects consumed on an average 60 to 90 meals per day regularly distributed over the light period, and the consumption and rate of feeding $(\mathrm{g} / \mathrm{mn})$ increased with age. The average length of time spent eating per meal was constant : $2 \mathrm{mn} 20 \mathrm{~s} \pm 19 \mathrm{~s}$ for LL chicks and $2 \mathrm{mn} 50 \mathrm{~s} \pm 24 \mathrm{~s}$ for LD chicks.

The LD chicks showed an increase in hourly food and water consumption beginning approximately six hours before the end of the light period, followed by a decrease in the last hour. A second peak in water intake was observed at the start of the period of illumination.

\section{STATISTICAL STUDY OF DISTRIBUTION OF HENS AT FEEDERS : APPLICATION TO STANDARIS}

\author{
J. M. FAURE et J. MALLARD \\ Station expérimentale d'Aviculture du Magneraud, I. N. R. A., \\ 17700 Surgères
}

Study from photographs of interindividual distances between hens at feeders shows that distribution is characterized by a grouping round central values, if compared with random distribution. This grouping seems to be due to a distribution of maximum spacing pattern when the 
number of hens exceeds 7 (on $2.75 \mathrm{~m}$ of feeders) and to an inter-individual attraction for values below 7 . It was possible to compute feeder ethological standards which are $13.5 \mathrm{~cm}$ of doublesided feeder by hen, i. $e$. about twice the standards used.

\title{
III. - Nutrition - feeding \\ MANIOC AND SWEET POTATOES, CARDOHYDRATE CONTAINING FEEDSTHFS FOR BROILERS
}

\author{
M. PALISSE et J. BARATOU \\ Société Sanders, \\ 17, Quai de l'Industrie, \\ 91260 Juvisy sur Orge
}

It is quite possible to introduce manioc and sweet potatoes into Broiler feeds on condition that they are supplied in the form of pellets.

The entertained characteristics seem to be correct for these two raw materials. Only the energy value is perhaps a little underestimated.

\section{FEEDING VALUE OF STORED AND ORGANIC ACID TREATED MAIZE FOR BROILERS}

\author{
J. CASTAING et J. MOAL \\ Association générale des Producteurs de mais, \\ 64000 Pau
}

The following organic acids, lactic and formic, have been used either alone or in association with propionic acid in order to preserve high moisture maize. The effect of propionic acid alone was also studied. The maize treated with lactic acid had to be rejected because of deterioration during storage.

After introduction of such treated maize into broiler diets, the growth rate and food consumption slightly decreased ( 6 to 7 p. roo and 5 p. roo respectively). Therefore, it seems that the treatments by organic acids decrease the palatability of stored maize. 